\title{
The Effectiveness of Peer Group Facilitators in Changing Teenagers' Attitudes Towards Bullying
}

\section{Masdum Ibrahim", Lucky Putra Pamungkas², and Heni Purnama1}

${ }^{1}$ Mental Health Nursing Departement STIKEP PPNI Jawa Barat, Bandung - West Java, Indonesia ${ }^{2}$ STIKEP PPNI Jawa Barat, Bandung - West Java, Indonesia

\section{ORCID}

Masdum Ibrahim: https://orcid.org/0000-0002-3789-6061

Corresponding Author: Masdum Ibrahim; email:

masdumibrahim@gmail.com

Published: 7 February 2022

Publishing services provided by Knowledge E

(c) Masdum Ibrahim et al. This article is distributed under the terms of the Creative Commons Attribution License, which permits unrestricted use and redistribution provided that the original author and source are credited.

Selection and Peer-review under the responsibility of the IVCN Conference Committee.
Abstract. Bullying can be terrifying, especially among students and teenagers. Bullying is sometimes carried out by fellow students at school. This study aimed to determine the effectiveness of peer group facilitators in changing teenagers' attitudes on bullying at SMKN 1 Cidaun. This was quantitative research, which applied a quasi-experimental two-group pretest-posttest design, using convenience sampling to recruit 40 respondents. The data collection was through a questionnaire of attitudes on bullying. Data were analysed using univariate analysis including frequency distribution, and bivariate analysis through ANCOVA. The results showed that most of the respondents were aged 16 (55 respondents, 68.8\%), 50 were female (62.5\%), and all respondents were Muslim. Based on bivariate analysis, there was a significant influence of peer group facilitators on teenagers' attitudes towards bullying ( $p<0.001$ ). It is recommended that teachers at SMKN 1 Cidaun implement peer group facilitators as an attempt to prevent bullying.

Keywords: peer group, facilitator, attitudes, bullying, teenagers

\section{Introduction}

Bullying is an increasingly worrying event, especially among students and teenagers, the facts show that the school environment is one of the places where bullying acts by fellow students [5]. Meanwhile, The International Center for Research on Women (ICRW) in [28] states that $84 \%$ of students in Indonesia experience bullying at school, this figure is higher than other countries in the Asian region such as Vietnam, Cambodia, Nepal, and Pakistan.

According to [14] Putri (2018), she stated in her research that bullying behavior occurs in various age ranges, the results of her research show that respondents who bullied were 13 years old (8.9\%), 14 years old (16.3\%), 15 years old (8.0). \%), 16 years (19.9\%), 17 years (17.8), and 18 years (29.2\%), the largest number of respondents who became perpetrators and victims were aged 16-18 years and at this age teenagers is currently a high school student. Adolescents who do bullying at school can be caused 
by bad experiences they have received from the school environment and the past they have experienced, students who have been victims of bullying will feel insecure and threatened while in their school environment [26].

The term peer group according to [18] is a peer group that is formed over time in the school environment or it can also be in the home environment based on age. Peer groups can be used to develop communication and self-identity in adolescents by groups of relatively the same age [4]. Based on research conduct by [22], the results their research show that $13 \%$ of students' bullying behavior at school is influenced by peers, and the remaining $87 \%$ is influenced by other factors such as parenting, selfesteem, school environment and the media.

In addition, based on research conduct by [16] stated there was a changed on students' attitudes among bullying behavior after sharing peer groups from initially negative to positive, this was evidenced by the average score at the time of the pretest 2.25 to 2.25 . 1.79 posttest. In contrast to research conduct by [23] who said his research that information services were effective for increasing anti-bullying attitudes, this was evidenced by the results of his research with an average pretest of 54.58 to 62.87 posttest.

Another study conducted by [18] also found that after conducting group discussions with a peer group facilitator, the score for bullying intentions in the experimental group decreased, while in the control group the score did not decrease, with a contribution to the experimental group of $67.8 \%$. on changes in bullying intensity. Similarly, research conducted by [24] which states that there are differences in anti-bullying knowledge during the pretest and posttest, the research results show that participants' anti-bullying knowledge increases significantly after sharing with peers.

According to [24] stated that peers have a very high role for bullying behavior to occur, and peers can be facilitators of anti-bullying programs with criteria, having sufficient information about bullying behavior and having communication in conveying information. According to [27] stated that the facilitator is an individual who is willing to provide facilities and information to others to change overall behavior. In addition, the facilitators is a substantively neutral person who manages the group process to help the group achieve its goals [25].

Based on researchers are interested in conducting a study entitled "Effectiveness of Peer Group Facilitators on Adolescent Attitudes Against Bullying", with the aim of knowing how the impact of peer group facilitators on adolescent attitudes towards bullying in the school environment and testing the effectiveness peer group facilitators on adolescent attitudes on bullying 
TABLE 1: Research Concept Framework
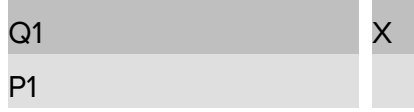

Q2

P2

\section{Method}

This research is a quantitative study using a quasi-experimental design with a two group pretest-posttest design

Information:

Q1: Measurement of adolescent attitudes towards bullying before being conducted by peer group facilitators.

$X$ : Implementation of peer group facilitator intervention.

Q2: Measurement of adolescent attitudes towards bullying after being conducted by peer group facilitators.

P1: Measurement of peer group facilitators on adolescent attitudes towards bullying in the control group (pretest).

P2: Measurement of peer group facilitators on adolescent attitudes towards bullying in the experimental group (pretest).

The research was carried out at SMKN 1 Cidaun located in Cidaun District, Cianjur Regency, West Java, on June 21 - July 5, 2021. The population of this study were students from SMKN 1 Cidaun, totaling 657 students. The number of samples this study was calculated using G-Power Software Version 3.1 using f-tests, ANCOVA: fixed effects, main effect and interaction with the assumption $=0.05$, Effect size $f=0.5$, power level $=0.8$, estimation the minimum sample size is 34 with an attrition rate of $10-15 \%$, totaling 6 , so the total sample size is 40 respondents. The sampling technique in this study will use tConvinience Sampling technique in accordance with the inclusion and exclusion criterias.

A. Inclusion Criteria

1) Able to communicate well

2) Have a smart phone.

3) Class X . students

B. Exclusion Criteria

1. Students who cannot enter school due to illness or permission based on notification from the school. 


\section{TABLE 2: Research Procedure}

$\begin{array}{ll}\text { Preparation } & \text { Researchers conducted a permit from the } \\ \text { phase (Pre Prep) } & \text { campus to conduct research at SMKN } 1 \text { Cidaun. } \\ \text { The researcher takes care of the research } \\ \text { permit letter to the school that is the place of } \\ \text { research. The researcher makes a time contract } \\ \text { with the school / BK teacher to start the } \\ \text { research. Researchers look for } 3 \text { videos about } \\ \text { bullying behavior that are in accordance with } \\ \text { situations that often occur at SMKN } 1 \text { Cidaun } \\ \text { on Youtube. Researchers make material about } \\ \text { peer group facilitators on bullying behavior in the } \\ \text { form of power points. The researcher chose } 8 \\ \text { facilitators, and the researcher worked together } \\ \text { with the BK teacher to select the facilitator. The } \\ \text { next researcher explains the aims and objectives } \\ \text { of this study, and provides an explanation of peer } \\ \text { group facilitators and bullying. The researcher } \\ \text { explains the duties of the facilitators and ensures } \\ \text { that each facilitator can carry out their duties as } \\ \text { resource persons, mediators and movers. } \\ \text { intervention) } \\ \text { After }\end{array}$

The instrument used in this study uses Indonesian with the Bullying Attitudes questionnaire. This instrument is used to measure students' attitudes towards bullying. 
TABLE 3: Demographic Characteristics of Control and Intervention Group Respondents.

\begin{tabular}{|c|c|c|c|c|c|}
\hline Charakteristic & $(\mathrm{N}=\mathbf{8 0})$ & $\begin{array}{l}\text { Control } \\
\mathrm{N}=40 \text { (\%) }\end{array}$ & $\begin{array}{l}\text { Intervention } \\
\mathbf{N}=\mathbf{4 0}(\%)\end{array}$ & P-value & statistic \\
\hline Age & & & & 0.170 & $\begin{array}{l}\text { Chi- } \\
\text { Square }\end{array}$ \\
\hline 16 & 55 (68.8\%) & 29 (72.5\%) & 26 (65.0\%) & & \\
\hline 17 & 25 (31.2\%) & 11 (27.5\%) & 16 ( $35 . \%)$ & & \\
\hline Gender & & & & 0.343 & $\begin{array}{l}\text { Chi- } \\
\text { Square }\end{array}$ \\
\hline Male & 30 (37.5\%) & 14 (35.0\%) & 13 (40.6\%) & & \\
\hline Female & 50 (62.5\%) & 26 (65.0\%) & 19 (59.4\%) & & \\
\hline Religion & & & & 1.000 & $\begin{array}{l}\text { Chi- } \\
\text { Square }\end{array}$ \\
\hline Islam & 80 (100\%) & 40 (100\%) & 40 (100\%) & & \\
\hline Kristen & 0 & 0 & 0 & & \\
\hline
\end{tabular}

\subsection{Univariate Analysis}

Univariate analysis in this study was conducted on each variable from the results this study to identify characteristics of the respondents, identify the influence peer group on adolescent attitudes towards bullying, and identify adolescent attitudes towards bullying pretest and posttest peer group facilitators. The respondents will be analyzed, namely the mean, standard deviation, the lowest value and the highest value.

\subsection{Bivariate Analysis}

Bivariate analysis is an analysis to see a relationship between the two variables in the research. In this study, bivariate analysis was conducted to analyze the effectiveness of peer group facilitators on adolescent attitudes towards bullying. The statistical test used in this study is ANCOVA. The results with statistical tests that have been carried out, is obtained that the value statistical test and the level of significance ( $p$-value) is comparing the $p$-value with the value of $(0.05)$. The hypothesis is said to be accepted if the $p$-value $<(0.05)$.

\section{Result}

Based on the table, the average respondents aged 16 years in both the control group and the intervention group, with the sex of respondents being female (65.5\%) in the control group and (59.4\%) in the intervention group. All respondents in this study embraced Islam (100\%). The results by the Chi-square analysis showed that there was no significant 
TABLE 4: Distribution of Demographic Data with Adolescent Attitudes towards Bullying ( $n=80)$

\begin{tabular}{|c|c|c|c|c|}
\hline Characteristic & Total $\mathbf{N}=\mathbf{8 0}$ & $\begin{array}{l}\text { Teenageers } \\
\text { Attitudes } \\
\text { Toward Bullying } \\
\text { (Mean } \pm \text { SD) }\end{array}$ & P-Value & Statistic \\
\hline Age 1617 & $\begin{array}{l}55(68.8 \text { \%) } 25 \\
(31.2 \%)\end{array}$ & $74.21 \pm 13.721$ & 1.000 & $\begin{array}{l}\text { Independet } \\
\text { T-Test }\end{array}$ \\
\hline $\begin{array}{l}\text { Gender Male } \\
\text { Female }\end{array}$ & $\begin{array}{l}30(37.5 \%) 50 \\
(62.5 \%)\end{array}$ & & 1.000 & \\
\hline Religion Islam & 80 (100\%) & & 1.000 & \\
\hline
\end{tabular}

TABLE 5: Components of Adolescents' Attitudes towards Bullying in the Intervention Group and the Control Group

\begin{tabular}{llllll}
$\begin{array}{l}\text { Componen } \\
\text { Attitudes }\end{array}$ & \multicolumn{3}{c}{ Intervention } & \multicolumn{2}{c}{ Control } \\
& \multicolumn{3}{c}{$\begin{array}{l}\text { Pre-test Mean Post-test } \\
\text { (SD) }\end{array}$} & $\begin{array}{l}\text { Mean (SD) } \\
\text { Pre-test } \\
\text { Mean (SD) }\end{array}$ & $\begin{array}{l}\text { Post-test } \\
\text { Mean (SD) }\end{array}$ \\
\hline Physic & 16.9500 & 18.9250 & 14.6750 & 14.3500 \\
& $(4.10722)$ & $(3.17351)$ & $(3.63309)$ & $(3.23879)$ \\
\hline Verbal & 18.2000 & 20.5000 & 17.6750 & 18.0500 \\
\hline Relational & $(3.14765)$ & $(2.76424)$ & $(4.70345)$ & $(4.06328)$ \\
& 15.5250 & 17.4500 & 14.3750 & 14.7000 \\
\hline Cyberbullying & $(2.81012)$ & $(1.94738)$ & $(2.88842)$ & $(2.67179)$ \\
& 19.2750 & 21.8750 & 17.8000 & 18.6250 \\
\hline Bullying & $(3.90914)$ & $(2.41987)$ & $(4.53590)$ & $(4.18598)$ \\
indirect & 6.8000 & 7.5750 & 7.1500 & 7.0750 \\
\hline & $(1.77157)$ & $(1.58337)$ & $(1.61006)$ & $(1.62335)$
\end{tabular}

difference between the intervention group and the control group in terms of age, gender, and religion.

The results of the Independent T-Test $t$, it shows that there is no significant value between age, gender and religion on adolescent attitudes towards bullying.

Based on table 4, the results show that there are an increase in the mean score in both groups from the pre-test and post-test to the four components of bullying attitude. The increase in the bullying component in the physical component of the intervention group, which initially had a mean score of 16,9500, increased to 18,9250 .

Based on table 5 , the results obtained in the intervention group that the mean pretest value was $76.74( \pm 12.725)$, this already tends to be good for bullying attitudes, but after the peer group the facilitator continues to improve with the mean post-test value of 86.33 ( \pm 8.657$)$. This shows a more significant increase the control group, because in the control group the mean pre-test value was $71.68( \pm 14.361)$, while the mean post-test of the facilitator group was $72.80( \pm 12.271)$.

Based on the description above, the post test results show an increased in adolescent attitudes towards bullying with a value of $P=0.000<(P=0.005)$ then $\mathrm{Ho}$ is rejected. 
TABLE 6: Differences in Scores of Adolescents' Attitudes to Bullying Before and After Given Peer Group Facilitators in the Control and Intervention Groups $(\mathrm{N}=80)$.

\begin{tabular}{|c|c|c|c|c|c|c|}
\hline Variabel & $\begin{array}{l}\text { Pre-Test } \\
\text { Mean }( \pm S D) \\
\text { (Min-Max) }\end{array}$ & $\begin{array}{l}\text { Post-Test } \\
\text { Mean }( \pm S D) \\
\text { (Min-Max) }\end{array}$ & $\mathbf{T}$ & $\begin{array}{l}\text { Mean } \\
\text { Differ- } \\
\text { ece }\end{array}$ & P-value & Statistik \\
\hline $\begin{array}{l}\text { Intervention } \\
(n=40)\end{array}$ & $\begin{array}{l}76.74 \\
( \pm 12.725) \\
51-97\end{array}$ & $\begin{array}{l}86.33 \\
( \pm 8.657) \\
63-101\end{array}$ & 4.016 & -9.5755 & 0.000 & $\begin{array}{l}\text { Paried Sam- } \\
\text { ple T-test }\end{array}$ \\
\hline $\begin{array}{l}\text { Control } \\
(n=40)\end{array}$ & $\begin{array}{l}71.68 \\
( \pm 14.361) \\
47-101\end{array}$ & $\begin{array}{l}72.80 \\
( \pm 12.271) \\
47-97\end{array}$ & 0.371 & $-1,125$ & .713 & $\begin{array}{l}\text { Paried Sam- } \\
\text { ple T-test }\end{array}$ \\
\hline
\end{tabular}

TABLE 7: The Effect of Peer Group Facilitators on Adolescent Attitudes towards Bullying $(n=80)$

\begin{tabular}{l|l|l|l|l|l|}
\hline Source & $\begin{array}{l}\text { Type III Sum df } \\
\text { of Squares }\end{array}$ & $\begin{array}{l}\text { Mean } \\
\text { Square }\end{array}$ & F & Sig. \\
\hline $\begin{array}{l}\text { Corrected } \\
\text { Model }\end{array}$ & $3658.585^{a}$ & 2 & 1829.293 & 16.015 & .000 \\
\hline Intercept & 16049.495 & 1 & 16049.495 & 140.511 & .000 \\
\hline Pretest & .073 & 1 & .073 & .001 & .980 \\
\hline Grup & 3537.781 & 1 & 3537.781 & 30.973 & .000 \\
\hline Error & 8795.102 & 77 & 114.222 & & \\
\hline Total & 518869.000 & 80 & & & \\
\hline Corrected Total & 12453.688 & 79 & & &
\end{tabular}

Meanwhile, in the control group, the post test results showed an increase in adolescent attitudes towards bullying and $p=.713>(p=0.005)$.

Based on Table-6 using the ANCOVA test, it was found that the level of scores of adolescents' attitudes towards bullying who received peer group facilitator intervention compared to groups that did not receive peer group facilitator intervention with a mean square $=3537,781, \mathrm{~F}=30,973, \mathrm{Sig}=.000(\mathrm{p}<0.005)$, it states that the results of hypothesis testing, namely $\mathrm{H}$ (null) is rejected and $\mathrm{H} 1$ is accepted. Concluded that there is a significant influence between peer group facilitators on adolescent attitudes towards bullying.

\section{Discussion}

The results of research in the intervention group, it showed that there were differences in adolescent attitude's towards bullying. There was a significant change before and after the peer group facilitator intervention with the mean pre-test value of $76.74( \pm 12.725)$, while the mean post-test was $( \pm 8.657)$. The minimum score before being given a peer group facilitator intervention was 51 while after being given a peer group facilitator it rose to 63 . The maximum score before being given a peer group facilitator was 97 , 
while after being given a peer group facilitator it rose to 101. Based on the results, there were significant differences in the bullying component in general. physical, where there is an increase in the mean value which was originally 16.9500 to 18.9250 . According to [21] in theory, physical bullying is a type of bullying that is visible, anyone can see it because of the physical touch between the bully and the victim. This behavior can occur because of the habit of someone who cannot control his actions and does not think about the consequences of his actions. Usually students do this action because of various triggers from their friends. In line with the research conduct by [9] the results of the study show that more than half $(70.9 \%)$ of respondents engage in physical forms of bullying in the form of hitting, more partly (58.2\%) physically. verbally in the form of dubbing, more partially (78.5\%) mentally in the form of silence (ignoring).

In addition, the above can happen because in this study most of the respondents were at the age of 16 years, namely (65.0\%) in the intervention group. According to [8] Athanasiou et al, (2018), it is stated that adolescents who are under or 16 years of age are more susceptible to being exposed to bullying. This statement is supported by [15] which states in her research that bullying behavior occurs in various age ranges, the results of her research show that respondents who do bullying are 13 years old (8.9\%), 14 years old (16.3\%), 15 years old ( 8.0\%), 16 years (19.9\%), 17 years (17.8), and 18 years (29.2\%), the highest number of respondents who became perpetrators and victims were aged 16-17 years and At this age, teenagers are in their period of becoming high school students. According to [17] adolescents are indeed an age that is vulnerable to delinquency. But at this age, teenagers should have started to take responsibility for what they did so that if a violation occurs, it is not in accordance with their developmental tasks. Where at this time teenagers at the age of 16 years according to [20] in his theory mentions as middle stage teenagers, where at this stage teenagers need the figure of a friend, because with many friends they will feel happy because they have the same nature. Meanwhile, at the age of 17 years, adolescents are in the stage of adolescence to adulthood which is characterized by the presence of self-characteristics of growing interest in intellectual function, seeking opportunities to unite with others, and forming a wall that separates people from others, privately and publicly. . Meanwhile, according to [10] stated in his theory that adolescence is a period of change, where at this stage adolescents experience development to the next stage. This means that what happened before will be a reference for what is happening now and in the future to influence new behavior patterns and attitudes.

The results of the study also showed most of the respondents were female in the intervention group (59.4\%). According to [3] theory, bullying can be carried out by 
both men and women, but its intensity is influenced by the socialization process they receive, not because of differences in the level of courage and physical size. However, it is different from the theory of [14] which says that "bullying behavior that occurs in adolescents has nothing to do with gender, because a teenage girl or boy can act as a perpetrator if there is an opportunity to do bullying and is supported by factors that influence the behavior of adolescents. certain factors such as the desire for revenge, lack of attention from the closest people, and the existence of hostility between individuals.

The results of the study showed that all respondents 80 (100\%) were Muslim. According to the theory put forward [19], if religion is related to social deviant behavior, it is most likely that religion is related to bullying behavior in adolescents. The logical way of thinking of adolescents also makes adolescents begin to be able to develop a hypothesis and systematically when getting answers to questions related to spirituality. Research shows that religiosity is positively correlated with prosocial behavior, including helping others who were previously unknown [6] . Supported by research conducted by [7] which shows that there is no influence between religion and bullying behavior in Islamic boarding schools with $p$ value $=0.370(p<0.05)$.

This study shows that is a significant influence of peer group facilitators on adolescent attitudes towards bullying with a value of $=.000(p<0.005)$. This is supported by the theory of [8], the method of group discussion with a facilitator is the recommended method to improve attitudes and motivation of adolescents in behavior. Based on research conducted by [11] there is an effect of health education using group discussions with facilitators on knowledge and attitude's.

Based on the posttest results in the intervention group, respondents who said they strongly agreed had been kicked intentionally by their friends, showing a decrease from the initial (17.5\%) to (5.0\%). Almost half of the total respondents said they did not agree when punching a friend for no reason from (35.0\%) to (47.5\%). This happens because of the increase in students' knowledge of bullying after peer group facilitators have conducted it, where the function of the facilitators themselves is as a motivator and resource person or as a source of information. In accordance with [13] theory, knowledge is the entire thought, concept and understanding of the world and its contents, including humans and their lives that are owned by humans. Meanwhile, according to [12] explains that an individual's knowledge can be increased by several factors, one of which is by providing information to someone. In addition, this is supported by the current Covid19 pandemic situation, in this era the learning process of students who initially often interacted directly, at this time students interacted through social media, so there was minimal risk of bullying directly. This is accordance with research conduct by 
[2]which states the online learning is safer than direct learning because it reduces the impact of physical bullying, besides online learning makes students more active in asking questions and expressing opinions without worrying about students' negative responses. other.

\section{Conclusion}

The results of research that has been done at SMKN 1 Cidaun and its discussion, the researchers can draw the conclusion that peer group facilitators are effective in preventing negative attitudes of teenagers towards bullying at SMKN 1 Cidaun. In addition, based on the function of the facilitator as a motivator and resource person, it can encourage students to be more direct and firm in their attitude

\section{References}

[1] Athanasiou K, Melegkovits E, Andrie EK, et al. Cross-national aspects of cyberbullying victimization among 14-17-year-old adolescents across seven European countries. BMC Public Health. 2018;18(1):1-15.

[2] Sobron A.N, Bayu, Rani, Meidawati. Persepsi siswa dalam studi pengaruhdaring learning terhadap minat belajar ipa. Scaffolding: Jurnal pendidikan Islam Dan Multikulturalismevol. 2019;1(2):30 - 38.

[3] Coloroso B. Penindas, tertindas, dan penonton. resep memutus rantai kekerasan anak dari prasekolah hingga SMU. Jakarta: Serambi; 2006.

[4] Damsar. Pengantar sosiologi politik. Jakarta: Prenadamedia Group; 2015.

[5] Ehan E. Bullying dalam pendidikan. 2016.

[6] Guo Q, Liu Z, Tian Q. Religiosity and prosocial behavior at national level. Psychology of Religion and Spirituality. 2020;12(1):55.

[7] Hamidah M. Religiusitas dan perilaku bullying pada santri di pondok pesantren. Jurnal Psycho Holistic. 2020;2(1):141-151.

[8] Handayani S, Emilia O, Wahyuni B. Efektivitas metode diskusi kelompok dengan dan tanpa fasilitator pada peningkatan pengetahuan, sikap dan motivasi remaja tentang perilaku seks pranikah. Berita Kedokteran Masyarakat. 2009;25(3):133.

[9] Herawati N, Deharnita D. Gambaran faktor-faktor penyebab terjadinya perilaku bullying pada anak. NERS Jurnal Keperawatan. 2019;15(1):60-66.

[10] Hurlock EB. Psikologi perkembangan suatu pendekatan sepanjang rentang kehidupan. Jakarta: Erlangga; 1997. 
[11] Kurniawati F. Pengaruh pendidikan HIV Dan AIDS menggunakan metode diskusi kelompok kecil dengan fasilitator terhadap tingkat pengetahuan dan sikap ibu rumah tangga di rusun begalon surakarta [Doctoral Dissertation]. Universitas Muhammadiyah Surakarta; Surakarta;2015.

[12] Mubarak W. Promosi kesehatan sebuah pengantar proses belajar mengajar dalam pendidikan. Yogyakarta: Graha IImu; 2007.

[13] Notoatmodjo S. Pendidikan dan perilaku kesehatan. Jakarta: Rineka Cipta; 2010.

[14] Pandie MM, Weismann ITJ. Pengaruh cyberbullying di media sosial terhadap perilaku reaktif sebagai pelaku maupun sebagai korban cyberbullying pada siswa kristen smp nasional makassar. Jurnal Jaffray. 2016;14(1):43-62.

[15] Putri ATK. Hubungan pola asuh orang tua dan penggunaan media sosial dengan perilaku bullying di sekolah pada remaja [Doctoral Dissertation]. Universitas Airlangga;Surabaya; 2018.

[16] Purnaningrum AW, Purwanto E, Ja'far M. Konseling kelompok dengan teknik role playing untuk membentuk sikap negatif siswa terhadap perilaku bullying. Jurnal Bimbingan Konseling. 2017;6(2):101-105.

[17] Rahmah H. Pengaruh peer group terhadap intensitas perilaku bullying pada usia anak. Al-Madrasah: Jurnal Pendidikan Madrasah Ibtidaiyah. 2018;Vol.3(1):17-26.

[18] Rahmatia P. Pengaruh fasilitator sebaya terhadap penurunan intensi bullying siswa Sma [Doctoral Dissertation]. Universitas Gadjah Mada; 2015.

[19] Santrock JW. Life-span development (perkembangan masa-hidup). Jakarta: Erlangga; 2012.

[20] Sarwono S. Psikologi remaja. Jakarta: Pt. Rajagrafindo Persada; 2011.

[21] Sejiwa T. Bullying: Panduan bagi orang tua dan guru mengatasi kekerasan di sekolah dan lingkungan. Jakarta: Grasindo; 2008.

[22] Septiyuni DA, Budimansyah D, Wilodati W. Pengaruh kelompok teman sebaya (peer group) terhadap perilaku bullying siswa di sekolah. Sosietas. 2015;5(1):13-16.

[23] Suhud K. Efektivitas layanan informasi dalam meningkatkan sikap anti bullying di smp baitussalam surabaya [Doctoral Dissertation]. Uin Sunan Ampel Surabaya; Surabaya;2017.

[24] Syahputri WH, Kumara A. Validasi modul "sharing" untuk fasilitator program antiperundungan. Gadjah Mada Journal Of Professional Psychology (Gamajpp). 2015;1(2):108-119.

[25] Thomas G. Facilitator, teacher, or leader? Managing conflicting roles in outdoor education. Journal of Experiential Education. 2010;32(3):239-254. 
[26] Tsiantis ACJ, Beratis IN, Syngelaki EM, et al. The effects of a clinical prevention program on bullying, victimization, and attitudes toward school of elementary school students. Behavioral Disorders. 2013;38(4):243-257.

[27] Widiastuti W, Ani Y, Munthe A. Penyuluhan orang tua dalam mendukung pendidikan anak sebagai fasilitator belajar. Prosiding Konferensi Nasional Pengabdian Kepada Masyarakat Dan Corporate Social Responsibility (Pkm-Csr). 2020;3:712-719.

[28] Yuniliza Y. Hubungan pengetahuan dan sikap remaja terhadap bullying di sman 3 kota bukittinggi. Maternal Child Health Care. 2020;2(3):219-225. 